\title{
Selectivity Index of Alpinia galanga Extract and 1'-Acetoxychavicol Acetate on Cancer Cell Lines
}

\author{
Muhammad Da'i ${ }^{1, *}$, Khairunnisa Azani Meilinasary ${ }^{1}$, Andi Suhendi ${ }^{1}$, Sari Haryanti² \\ ${ }^{1}$ Pharmaceutical Chemistry Department, Faculty of Pharmacy, Universitas Muhammadiyah Surakarta, Surakarta, Indonesia \\ ${ }^{2}$ The Center for Research and Development of Traditional Medicinal Plants and Medicines (B2P2TOOT), Karanganyar, \\ Indonesia
}

\begin{abstract}
Previous research stated that galangal (Alpinia galanga) extract has a potential as cytotoxic agent with active compound of 1'-Acetoxychavicol Acetate (ACA). The objective of this study was to determine the selectivity of ethanol extract, ethyl acetate fraction, and methanol fraction of of galangal, and ACA on cancer cell lines. Cytotoxic activity was carried out using the MTT method on T47D breast cancer, WiDr colon cancer, HeLa cervical cancer, and Vero normal cell lines. The results showed that galangal ethanol extract and its fractions had selectivity index equal to or less than 2 on cancer cells. Meanwhile, ACA had selectivity index more than 3 on T47D cell and HeLa cell. ACA showed a strong cytotoxic activity against cancer cells T47D, HeLa, and WiDr with $\mathrm{IC}_{50}$ values of $3.14,7.26$, and 12.49 $\mu \mathrm{g} / \mathrm{ml}$, respectively. Based on data, it could be concluded that ACA was the most selective to inhibit T47D cell with a selectivity index of 6.6.
\end{abstract}

Keywords: 1'-Acetoxychavicol acetate, galangal (Alpinia galanga), selective index, cytotoxic

\section{INTRODUCTION}

Cancer is a disease that causes high mortality in the world. In 2012, 8.2 million deaths have been caused by this disease (Pusat Data dan Informasi, 2015). Chemotherapy, surgery, radiation, and hormonal therapy are the number of common therapies for cancer patients; however, they require high costs as well as a number of side effects due to the low selectivity of therapy. Researchers therefore continue to conduct research to obtain more selective anticancer drugs. One of the potential ingredients to be developed as anti-cancer with better selectivity is herbal medicines. One source of herbal medicines that has been traditionally used for cur- ing cancer is galangal (Alpinia galanga) (Kuntorini, 2005).

Zaeoung, et al., (2005) stated that Alpinia galanga as an antioxidant and free radicals scavenger has cytotoxic activity against MCF7 (breast adeno-carcinoma) and LS174T (intestinal adenocarcinoma) cells. Galangal extract at the dose of 225,450 , and $750 \mathrm{mg} / \mathrm{kgBW} /$ day could increase the apoptosis process and reduce proliferative activity in breast cancer cells (Hartono, 2009). Cytotoxic

Submitted: June 17, 2019

Revised: June 27, 2019

Accepted: June 27, 2019

*Corresponding author: muhammad.dai@ums.ac.id 
activity, described as $\mathrm{IC}_{50}$ value, on HeLa cervical cancer cell line of galangal extract from three local markets were $13.26,36.32$, and $>100 \mu \mathrm{g} / \mathrm{mL}$ in order. Meanwhile, Alpinia galangal extract (AGE) from Pasar Legi (Surakarta, Indonesia) on MCF7 and T47D breast cancer cell lines have $\mathrm{IC}_{50}$ value of 15.80 and $12.50 \mu \mathrm{g} / \mathrm{mL}$, respectively (Suhendi et al., 2017). Galangal contains several phenylpropanoid compounds, including 1'-acetoxychavicol acetate (ACA), 1'-acetoxyeugenol acetate, trans-pcoumaril diacetate, 1'hydroxyccapsol acetate, and trans-coumaryl alcohol (Matsuda, et al., 2005). ACA is the main composition of Alpinia galanga (Baradwaj, et al., 2017; Hasima, et al., 2010).

ACA has cytotoxic against various cancer cell lines such as A549 cancer cells (lung cancer), SNU638 (stomach cancer), HCT116 (colon cancer), HT1080 (fibrosarcoma), and HL60 (leukemia) with $\mathrm{IC}_{50}$ values of $8.14,1.27,1.77,1.20$, and $2.39 \mu \mathrm{g} / \mathrm{mL}$, respectively (Nam, et al., 2005). Another research by Zeng, et al., (2015) revealed that ACA showed cytotoxic activity on HeLa (cervical cancer), A549 (lung cancer), HepG-2 (liver cancer) and SMMC-7721 (liver cancer) with IC50 values of $85.1,64.44,74.51$, and $61.27 \mu \mathrm{g} / \mathrm{mL}$, respectively. This study was conducted to determine the selectivity of galangal extract and ACA in breast cancer cells (T47D), cervical cancer cells (HeLa) and colon cancer cells (WiDr) compared to normal cells (Vero). The finding would serve as a basic for the further development targeted on cytotoxic research.

\section{METHOD}

Materials that were used in this study include evaporator (Heidolph), waterbath (Changzhou Nuohai XMTD-204), analytical balance (Sartorius), micro pipette (Soccorex), LAF (Nuaire), hemocytometer (Marienfield Germany), 96-well-plate (Iwaki), conical tube, ELISA reader (BioTek), incubator (Binder), microscope (Olympus), galangal rhizome (Laboratorium Balai Besar Penelitian dan Pengembangan Tanaman Obat dan Obat Tradisional, Tawangmangu, Indonesia ), Ace- toxychavicol acetate (LKT Laboratories Inc.), Roswell Park Memorial Institute (RPMI 1640, Gibco), dimethyl sulfoxide (DMSO) (Merck), Fetal Bovine Serum 10\% (FBS, Gibco), penicillin-streptomycin 1\% (Gibco), tripsin (Gibco), sodium dodecyl sulfate (SDS, Gibco), MTT (Sigma), fungizone (Gibco). Cell lines (T47D, HeLa, and WiDr) were obtained from Laboratorium Balai Besar Penelitian dan Pengembangan Tanaman Obat dan Obat Tradisional Tawangmangu, Karanganyar, Indonesia (B2P2TOOT).

\section{Extraction and fractionation}

Extraction was conducted by maceration process with ethanol $95 \%$ as solvent within 3 days. Liquid extract was then evaporated to obtain the thick extract. Ten milligrams of thick extract were dissolved in $10 \mathrm{~mL}$ of distilled water and $10 \mathrm{~mL}$ of ethyl acetate in a separating funnel. The top layer (ethyl acetate partition) was taken and evaporated in a water bath covered in aluminum foil to form the ethyl acetate fraction. Subsequently, the ethyl acetate fraction was dissolved using methanol (methanol fraction). The fractionation was done in triplicates.

\section{MTT Assay}

The MTT reagent $(0.5 \mathrm{mg} / \mathrm{mL})$ was prepared by taking $1 \mathrm{~mL}$ of stock solution of MTT in PBS $(50 \mathrm{mg} / 10 \mathrm{~mL})$ and diluted it by media up to $10 \mathrm{~mL}$ (for 1 well plate). Once disposed, the cell was washed with PBS and $100 \mu \mathrm{L}$ MTT reagent was added to each well, including media control (without cells). The cell, following this, was incubated for 2-4 hours in a $\mathrm{CO}_{2}$ incubator. The cell was then examined with an inverted microscope. After formazan was clearly formed, a stopper reagent (SDS $10 \%$ ) was added in $0.1 \mathrm{~N} \mathrm{HCl}$. The plate was wrapped with paper or aluminum foil and incubated in a dark place at room temperature for one night. Absorbance of each well was then read by an ELISA reader at $\lambda=595 \mathrm{~nm}$. $\mathrm{IC}_{50}$ was calculated based on linier regression equation between viability cells and concentration of samples (Mosmann,1983). 


\section{Selectivity Index Analysis}

Selectivity Index (SI) is obtained from the $\mathrm{IC}_{50}$ value of a compound against normal cells divided by the $\mathrm{IC}_{50}$ value of cancer cells (Aljewari, et al., 2010; Badisa, et al., 2006). Compounds are classified as high selectivity if the SI value is $>3$ and less selective if the SI value is $<3$ (Sutejo, et al., 2016).

\section{RESULTS AND DISCUSSION}

The material used in this study is galangal rhizomes obtained from the Center for Research and Development of Traditional Medicinal Plants and Medicines (B2P2TOOT) Tawangmangu, Karanganyar Regency, Central Java. Morphologically, the fresh galangal rhizomes are characterized with small and thick, fleshy, cylindrical about 2-4 $\mathrm{cm}$ in diameter, and branched. The outer parts are rather brown, reddish or pale greenish yellow with white and reddish, hard glossy scales, and while the inside part is white. The flesh of old rhizomes is rough fibrous. When getting dried, the rhizomes turn somewhat greenish, and the fibers become hard and tough. Dried rhizome was then extracted by maceration using $96 \%$ ethanol as solvent. The result of thick extract was $73.09 \mathrm{~g}$ with yield of $8.12 \%$.

To group chemical constituents in extract, fractionation was conducted. The method used in fractionation of galangal extract was a liquid-liq-

uid extraction. Grouping chemical constituent was based on distribution constanta of chemicals in non-immiscible solvent (Berthod and Carda-Broch, 2004). The target of fractionation was to obtain the rich fraction of active constituent. One of active compounds of galangal extract is ACA, which has potential as an anticancer (Asri and Winarko, 2016). Fractionation results showed the yield of ethyl acetate fraction obtained as 7.43 gram, higher than the methanol fraction as 1.30 gram.

The cytotoxicity determination of galangal ethanol extract, ethyl acetate fraction, methanol fraction and ACA compounds were carried out using the MTT method on breast cancer cells (T47D), cervical cancer cells (HeLa), colon cancer cells (WiDr), and normal cells (Vero). Morphology of cancer cells after treated by samples is shown in Figure 1.

The value of $\mathrm{IC}_{50}$ of samples were calculated based on regression equation (Figure 2) of $\%$ viability cell percentage vs concentration. The value of $\mathrm{IC}_{50}$ of samples on three cancer cells showed a strong cytotoxic activity (Table 1). Due to $\mathrm{IC}_{50}$ values, the ACA is viewed to have the most active cytotoxic activity against all cancer cells tested. Ethyl acetate fraction has better cytotoxic activity compared to ethanol extract and methanol fraction. As ACA compounds are semi-polar, they could dissolve more in ethyl acetate. The compounds have the most active cytotoxic activity in T47D cells followed by HeLa cells and WiDr cells. $\mathrm{IC}_{50}$ values of

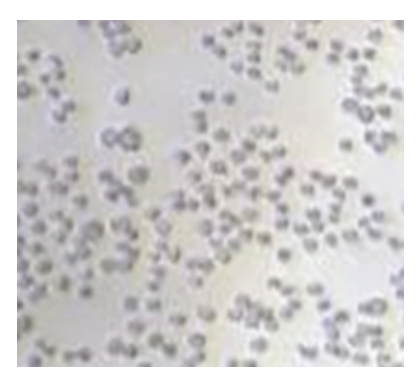

$\mathrm{HeLa}$

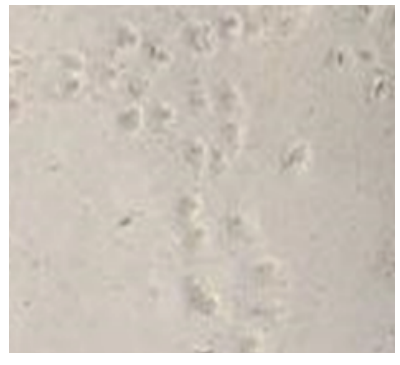

WiDr

Figure 1. Morphology of cancer cells after administration of ACA at a dose of $10 \mu \mathrm{g} / \mathrm{mL}$. The cells were observed after $24 \mathrm{~h}$ of treatments under an inverted microscope with magnification of $100 \mathrm{x}$. 
Da'i, et al., 2019

Indones. J. Cancer Chemoprevent., 10(2), 95-100

Table 1. Selectivity index of extract, ethyl acetate, methanol fractions and ACA on T47D, HeLa, WiDr, and Vero cell lines.

\begin{tabular}{|c|c|c|c|c|c|c|c|c|}
\hline \multirow{2}{*}{ Samples } & \multicolumn{2}{|c|}{ T47D } & \multicolumn{2}{|c|}{ HeLa } & \multicolumn{2}{|c|}{ WiDr } & \multicolumn{2}{|c|}{ Vero } \\
\hline & $\mathrm{IC}_{50}(\mu \mathrm{g} / \mathrm{mL})$ & SI & $\mathrm{IC}_{50}(\mu \mathrm{g} / \mathrm{mL})$ & SI & $\mathrm{IC}_{50}(\mu \mathrm{g} / \mathrm{mL})$ & SI & $\mathrm{IC}_{50}(\mu \mathrm{g} / \mathrm{mL})$ & SI \\
\hline Ethanol extract & $44.93 \pm 1.08$ & 1.6 & $40.00 \pm 0.55$ & 1.9 & $66.11 \pm 3.15$ & 1.1 & $74.06 \pm 7.13$ & 1 \\
\hline Ethyl acetate fraction & $42.29 \pm 3.28$ & 1.3 & $35.54 \pm 0.44$ & 1.5 & $48.81 \pm 1.68$ & 1.1 & $53.66 \pm 2.57$ & 1 \\
\hline Methanol fraction & $40.49 \pm 2.13$ & 1.8 & $35.76 \pm 1.53$ & 2 & $55.24 \pm 1.62$ & 1.3 & $72.77 \pm 0.35$ & 1 \\
\hline ACA & $3.14 \pm 0.14$ & 6.6 & $7.26 \pm 0.12$ & 3.5 & $12.49 \pm 1.09$ & 2 & $25.25 \pm 0.92$ & 1 \\
\hline
\end{tabular}

ACA in T47D, HeLa, and WiDr were found in 3.14; 7.26 , and $12.49 \mu \mathrm{g} / \mathrm{mL}$, respectively. The potential of a compound is classified as strong cytotoxic agent if the $\mathrm{IC}_{50}$ value $<20 \mu \mathrm{g} / \mathrm{mL}$, moderate if the
$\mathrm{IC}_{50}$ value $<50 \mu \mathrm{g} / \mathrm{mL}$, and iweak if the $\mathrm{IC}_{50}$ value $>$ $50 \mu \mathrm{g} / \mathrm{mL}$ (Ellithey, et al., 2014) (Table 1). From the results obtained, it can be concluded that ACA has strong cytotoxic properties.
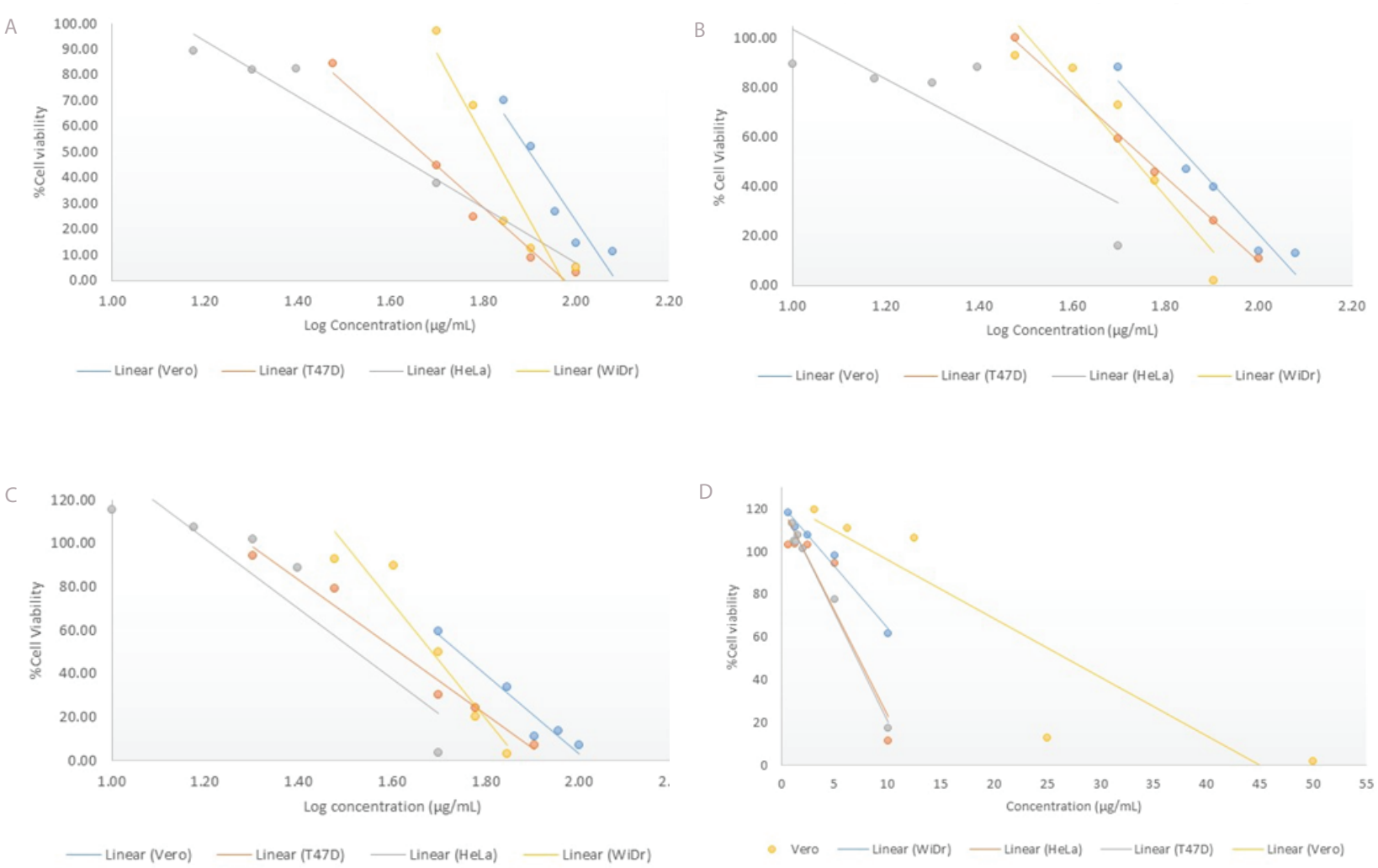

Figure 2. Graphics of correlation of viability cell percentage vs concentration of ACA, ethanol extract of Alpinia galangal, and its fractions. Percentages of viable cells were obtained based on colorimetric reaction of MTT that reduced by reductase enzyme resulting formazan and the absorbance was measured on wavelength 550 $\mathrm{nm}$. Ethanolic extract showed negative slope that indicated the cytitoxic effect and ACA most potent to inhibit the cell growth on Vero, T47D, HeLa, and WiDr cell lines. A: ethanol extract of Alpinia galangal; B: methanol fraction Alpinia galangal; C: ethyl acetate fraction Alpinia galangal; D: 1'-acetoxychavicol acetate (ACA). 
The selectivity of chemopreventive agents means that only cells identified as cancer cells are attacked. The higher the selectivity index of a compound to cells, the more selective the compounds to kill or inhibit the growth of a cancer cell with the smaller effect on normal cells. The small selectivity index indicates that the compound is less toxic to normal cells rather than to cancer cells. Compounds with high SI values offer the potential for safer and more effective therapy in cancer therapy (Segun, et al., 2019). Based on the test results galangal ethanol extract, ethyl acetate fraction, and methanol fraction are found to be less selective for all tested cells $(\mathrm{SI}<3)$. Meanwhile, ACA is selective for T47D and HeLa cells with SI $>3$ and less selective for WiDr cells. The results of this research need a further study to determine the anticancer potential in animal models. Due to the lack of selectivity and many side effects (such as fatigue, nausea, alopecia and others) of cancer chemotherapy, these finding promising to develop as selective anticancer agent (González-Arriagada, et al., 2013; Ihbe-Heffinger, et al., 2013).

\section{CONCLUSION}

The extract and fractions of Alpinia galangal ethanol extract have potential cytotoxic activity on T47D, HeLa and WiDr. Compound 1 '-acetoxychavicol acetate has a strong cytotoxic activity against cancer cells T47D, HeLa and WiDr with IC50 values of 3.14, 7.26 and $12.49 \mu \mathrm{g} / \mathrm{ml}$, respectively and selective for T47D breast cancer cells with selectivity index of 6.6.

\section{ACKNOWLEDGMENT}

This work has been funded by Universitas Muhammadiyah Surakarta by PINPRU research scheme.

\section{REFERENCES}

Aljewari, H., AL-Faisal, A.H.M. and Nader, M., 2010, In vitro Cytotoxic Activity of the L-asparaginase Extracted and Purified from Pathogenic Escherichia coli Against four Leukemic cell lines. Presented at the 2nd Annual International Conference of Northest Pharmacy Research, Faculty of Pharmacy, Mahasarkham University, Thailand, pp. 21-23.

Asri, A. and Winarko, S., 2016, Antiproliferative Activity by Ethanolic Extract of Red Alpinia galanga (L) Willd in Inoculated Breast Carcinoma Cells of C3H Mice, J. Adv. Med. Pharm. Sci., 5, 1-9.

Badisa, R.B., Ayuk-Takem, L.T., Ikediobi, C.O. and Walker, E.H., 2006, Selective Anticancer Activity of Pure Licamichauxiioic-B Acid in Cultured Cell Lines, Pharm. Biol., 44, 141-145.

Baradwaj, R.G., Rao, M.V. and Kumar, T.S., 2017, Novel purification of 1'S-1'-Acetoxychavicol acetate from Alpinia galanga and its cytotoxic plus antiproliferative activity in colorectal adenocarcinoma cell line SW480, Biomed. Pharmacother., 91, 485-493.

Berthod, A. and Carda-Broch, S., 2004, Determination of liquid-liquid partition coefficients by separation methods, J. Chromatogr. A, Estimation of Physicochemical Properties by Chromatographic and Electrophoretic Techniques, 1037, 3-14.

Ellithey, M.S., Lall, N., Hussein, A.A. and Meyer, D., 2014, Cytotoxic and HIV-1 enzyme inhibitory activities of Red Sea marine organisms. BMC Complement, Altern. Med., 14, 77.

González-Arriagada, W.A., de Andrade, M.A.C., Ramos, L.M.A., Bezerra, J.R.S., Santos-Silva, A.R. and Lopes, M.A., 2013, Evaluation of an educational video to improve the understanding of radiotherapy side effects on head and neck 
cancer patients, Support. Care Cancer Off. J. Multinatl. Assoc. Support. Care Cancer, 21, 2007-2015.

Hartono, N.W.B., 2009, Pengaruh Alpinia galanga (Lengkuas) Terhadap Aktivitas Proliferasi Sel dan Indeks Apoptosis Pada Adenokarsinoma Mencit C3H (Thesis masters). UNIVERSITAS DIPONEGORO.

Hasima, N., Aun, L.I.L., Azmi, M.N., Aziz, A.N., Thirthagiri, E., Ibrahim, H. and Awang, K., 2010, 1 'S-1'-Acetoxyeugenol acetate: A new chemotherapeutic natural compound against MCF-7 human breast cancer cells, Phytomedicine, 17, 935-939.

Ihbe-Heffinger, A., Paessens, B., Berger, K., Shlaen, M., Bernard, R., von Schilling, C. and Peschel, C., 2013, The impact of chemotherapy-induced side effects on medical care usage and cost in German hospital care--an observational analysis on non-small-cell lung cancer patients, Support. Care Cancer Off. J. Multinatl. Assoc. Support. Care Cancer, 21, 1665-1675.

Kuntorini, E.M., 2005, Botani Ekonomi Suku Zingiberaceae Sebagai Obat Tradisional oleh Masyarakat di Kotamadya Banjarbaru, BIOSCIENTIAE, 2. Matsuda, H., Ando, S., Morikawa, T., Kataoka, S. and Yoshikawa, M., 2005, Structure-activity relationships of 1'S-1'-acetoxychavicol acetate for inhibitory effect on NO production in lipopolysaccharide-activated mouse peritoneal macrophages, Bioorg. Med. Chem. Lett., 15, 1949-1953.

Mosmann, T, 1983, Rapid colorimetric assay for cellular growth and survival: Application to prolif- eration and cytotoxicity assays, J. of Immunol. Methods, 65(1-2), 55-63.

Nam, J.-W., Kim, S.-J., Han, A.-R., Lee, S.-K. and Seo, E.-K., 2005, Cytotoxic phenylpropanoids from the rhizomes of Alpinia galanga, J. Appl. Pharmacol., 13, 263-266.

Pusat Data dan Informasi, K.R., 2015, Infodatin_Stop Kanker.

Segun, P.A., Ogbole, O.O., Ismail, F.M.D., Nahar, L., Evans, A.R., Ajaiyeoba, E.O. and Sarker, S.D., 2019, Resveratrol derivatives from Commiphora africana (A. Rich.) Endl. display cytotoxicity and selectivity against several human cancer cell lines, Phytother. Res., 33, 159-166.

Suhendi, A., Wikantyasning, E.R., Setyadi, G., Wahyuni, A.S. and Da'i, M., 2017, Acetoxy Chavicol Acetate (ACA) Concentration and Cytotoxic Activity of Alpinia galanga Extract on HeLa, MCF7 and T47D Cancer Cell Lines, Indones. J. Cancer Chemoprevention, 8, 81-84.

Sutejo, I.R., Putri, H. and Meiyanto, E., 2016, The Selectivity of Ethanolic Extract of Buah Makassar (Brucea javanica) on Metastatic Breast Cancer Cells, J. Agromedicine Med. Sci., 2, 1-6.

Zaeoung, S., Plubrukarn, A. and Keawpradub, N., 2005, Cytotoxic and free radical scavenging activities of zingiberaceous rhizomes, Warasan Songkhla Nakharin Sakha Witthayasat Lae Technol.

Zeng, Q., Lu, C.-L., Zhang, X. and Jiang, J.-G., 2015, Isolation and identification of ingredients inducing cancer cell death from the seeds of Alpinia galanga, a Chinese spice, Food Funct., 6, 431-443. 